\title{
Analysis of Symbolic Interaction on Effective Communication of Deaf Student of Darul Ashom Islamic Boarding School Yogyakarta
}

Khoniq Nur Afiah ${ }^{1^{*}}$

${ }^{1}$ Sunan Kalijaga State Islamic University, Yogyakarta, Indonesia
Article Information

Submitted July 16, 2021

Revised August 30, 2021

Accepted September 08, 2021

Published October 01, 2021

\begin{abstract}
Communication is a primary need for every human being, including people with disabilities. Disability people, such as deaf people, also have interaction patterns to communicate effectively. Effective communication patterns can provide teaching and learning fluently at the Darul Ashom Islamic Boarding School for the Deaf, Yogyakarta. This research aims to study the effective communication design by teachers with deaf students in the Darul Ashom Islamic Boarding School for the Deaf, Yogyakarta. This study uses a qualitative descriptive method with Herbert Blumer's symbolic interaction analysis perspective. This study indicates that the interaction pattern between deaf students and the teacher uses several symbols in the interaction process, such as spoken language, body language, sign language, and picture symbols. These symbols emerge and are used in the interaction process, especially the teaching and learning technique and memorization. The activities carried out by the students such as Tahsin, memorization, fiqh and hadith studies, murojaah and simaan also illustrate the use of symbolic interactions. The symbolic interaction has a meaning that the communicant and communicator understand to achieve effective communication.
\end{abstract}

Keywords: Symbolic Interaction, Deaf, Effective Communication, Islamic Boarding School.

\section{Introduction}

The basis for implementing inclusive education is Article 4 (1) Government Regulation No. 19 of 2005 concerning National Education Standards. The regulation controls the administration of inclusive education, including teachers and educational institutions providing inclusive education. This regulation is crucial because currently, many educational institutions provide inclusive education, including special Islamic boarding schools that open access for people with disabilities. For example, the Hidayatul Qur'an Islamic Boarding School (Kholisnawati, 2016), the Baabussa'adah Islamic Boarding School (Ruslan, 2019), and the Ainul Yakin Islamic Boarding School (Rafif, 2020). Special education institutions for people with disabilities fulfill disabilities' rights. Support for disabled-friendly learning facilities and systems will provide convenience for students with disabilities to get maximum

\footnotetext{
*Author Correspondence: Khoniq Nur Afiah, khoniqnurafiah@gmail.com, Sunan Kalijaga State Islamic University, Jl. Laksda Adisucipto, Papringan, Caturtunggal, Depok, Sleman, Yogyakarta 55281, Indonesia
} 
religious education (Huda, 2018). In addition to supporting learning facilities and systems, another important component is the teaching staff. The skills and competencies of qualified teachers in providing inclusive education services will support the success of inclusive education (Musoliyah, 2019). For people with disabilities, education will lead them to live independently without relying on others. Educational institutions or Islamic boarding schools with disabilities are expected to provide education and skills that deliver children with special needs to survive.

Children with disabilities or Children with Special Needs (ABK) have physical, mental, and social abnormalities. There are four categories in children with special needs, such as visual impairment (blindness), hearing impairment (deaf), speech impairment, and limb function disorders or physically disabled (Efendi, 2006). In addition to the categories mentioned above, children who have mental disorders can also be called children with special needs, such as having more mental disorders (supernormal) who have superior talents. However, some children have minimal mental abilities (abnormal), referred to as mentally disabled. Abnormalities in the social aspect in children are called maladaptive. Abnormalities in social aspects cause individuals to experience difficulties adjusting to the environment (Abdullah, 2013).

The disabilities require special attention and assistance from teachers who have excellent competence. One of the skills that must be mastered by special school teachers or educational institutions for children with special needs is communication skills. In social reality, communication is an important component for each individual or group to carry out their lives.
Communication has a broad purpose, including helping to detect the various needs of humans. In the dynamics of social life, communication has an absolute position as a prerequisite for people to make adjustments. Communication skills will affect the process of self-actualization in individuals (Saihu, 2019).

The reasons that encourage humans to communicate include: first, humans are zoon politicons. Humans cannot live independently, and they need other people. The inability to live independently will require humans to interact or contact other people. Second, the purpose of communication is as a space to exchange and present their thoughts, ideas, or emotions. In communication, there is an exchange of information or messages from each actor in factual information as practiced by an educator who transfers knowledge to students (Nida, 2013).

The government regulation on Standards for the Implementation of Inclusive Education led this research to examine the effective communication patterns in the Darul Ashom Islamic Boarding School Yogyakarta. This study also examines the techniques and skills of teachers in creating effective communication with children with special needs. This research is crucial to be carried out to find an overview of how teachers communicate with children with special needs/disabilities.

The analysis process in this research uses Herbert Blumer's symbolic interaction analysis. The symbolic interaction theory develops concurrently with the social structure and forms social interaction symbols. Two important things are the basic assumptions of symbolic interaction theory that humans in society always carry out social interactions and that interaction or 
communication always presents symbols.

Fishter (in Maisyaroh, 2016) reports that the real condition of society is the part highlighted by the symbolic interaction theory. Humans can maintain symbols in social interaction, contain cultural meanings, are interconnected, social, and have a concept of thought. Thus, every social interaction or communication always begins and ends with consideration for each individual.

Herbert Blumer stated that the orientation possessed by symbolic interaction is to form meaning and substance (Laksmi, 2018). The symbolic interaction process forms these meanings and substances. Thus, meaning, language, and thought are the theory's three main principles.

The meaning in symbolic interaction theory is not related to objects but develops through social interaction between humans (Siregar, 2012). This meaning is in the context of relationships within the family and society. The meaning is constructed and modified through meaning carried out by individuals involved in social interaction.

Language in symbolic interaction is an attempt to give a name to something. Language as a source of meaning develops continuously in social interactions (Solin, 2010). Language is also an instrument or tool. Communication will transpire between humans if individuals understand and use identical language.

Thought is the impact on the meaning transferred by someone to a symbol. The rationale is that a mental process changes meanings, names, and symbols. Thought includes imagination, which can provide ideas even about something unknown based on the knowledge possessed (Ritzer \& Goodman, 2002).
Interactions between individuals and groups will involve language and are then positioned as symbols. The communicator gives the symbols, and the communicant will capture the meaning of the symbols. The process of capturing meaning, or Blumer calls it meaning, involves thinking. This thinking influences the individual or the communicant in interpreting a message behind the given symbol (Ahmadi, 2008).

Several previous studies that discussed symbolic interactions include Tamunu, who analyzed symbolic interactionism on students with deviations behavior (Tamunu et al., 2018). The symbolic interactionism theory helps analyze how deviant behavior emerges and how internalizing deviant knowledge leads to deviant actions.

Maghfirah and Mahadian also conducted research related to the symbolic interaction of teachers and students in the "Matahari Kecil" community (Maghfira \& Mahadian, 2018). The symbolic interactionism perspective utilized in Tamunu, Magfirah, and Mahadian research is George Herbert Mead. Maghfirah and Mahadian revealed that meaning or selfconcept for students and teachers is symbolic interaction among teachers and students. The self-concept in this study is that the teacher feels grateful, becomes a better person, and has the passion for applying the importance of education to students. Students in symbolic interactions also deliver several meanings or self-concepts, such as being more confident, passionate about reaching their goals, and becoming a more qualified person.

Hutapea examines self-identification through communication symbols (Hutapea, 2016). Hutapea focuses on identifying how the internalization process emerges for drug users. Arranged, Hutapea reveals a chronology 
of drug users' behavior in society. Indirectly, the theory of symbolic interactionism helps Hutapea identify the factors and processes of a drug user's behavior as a deviation. The process is studying Mead's concept of mind, self, society. Restendy conducts communication research on disabled communities. This research focuses on breakthroughs in teaching the Qur'an at the Extraordinary Qur'an Education Park (TPQLB) Indonesia, based in Tulungagung, East Java (Restendy, 2019). Restendy said that the deaf students communicate in interpersonal communication to get the material given by the teacher at TPQLB directly.

Liga and Fernando also researched the process of designing a communication application for the deaf based on Android (Liga \& Fernando, 2017). Liga and Fernando's research starts from the problem of the general public's lack of understanding of sign language, which hinders communication to the deaf. In order to solve this problem, Liga and Fernando designed an android-based application called "Deaf Communication," which aims to assist communication among the deaf and normal person and vice versa in communicating.

Malinda, Suzu S. Azeharie examines symbolic interactionism communication among deaf workers and guests at "Kopi Tuli Cafe" Depok. Malinda explained that communication among deaf workers and guests uses sign language, while guests who cannot use it use pictures in the menu list they want to choose (Mailinda \& Azeharie, 2019). Yani, Shilvy, and Anjana examined the communication patterns of classroom teachers to people with disabilities (Yani Hendrayani et al., 2019). This study states that communication among teachers and students with disabilities is verbal and nonverbal communication, interactional and transactional communication patterns. This study also remarked on the obstacles in the process of delivering learning.

There are several studies on communication for the deaf or the disabled. No research focuses on studying effective communication among deaf students, or more specifically, on the communication of deaf students who memorize the Qur'an. The study of effective communication patterns in deaf students who memorized the Qur'an becomes an interesting study, especially when using Herbert Blumer's analysis of symbolic interactions. The Darul Ashom Islamic Boarding School for the Deaf is comfortable and friendly for the deaf. The communication is effective so that teaching and learning activities conduct smoothly and the material can be transferred properly. This encouragement made the researchers examine more deeply the patterns of interaction among deaf students who memorized the Qur'an at the Darul Ashom Islamic Boarding School, Yogyakarta.

\section{Method}

This study uses a qualitative descriptive method that focuses on providing an accurate description of the character of a particular individual, symptom, or group. Data collection techniques using observation, interviews, and documentation (Azwar Saifuddin, 2011). This study uses two types of data sources, specifically primary and secondary data (Sugiono, 2017). The primary data is interviews with two teachers/ustadzah and three deaf students. Primary data were also acquired from observations during the study. 
Data collection starts with observations at the Darul Ashom Islamic boarding school. The observation technique surveys the interaction process in the Darul Ashom Islamic Boarding School circumstances. Observational data relates to the interaction process, such as data on techniques and strategies used by the ustadzah to achieve effective interaction with deaf students.

The next data collection used in-depth interview techniques. The researcher interviewed two teachers/ustadzah and three deaf students in symbolic interactions. Interview data emphasizes the process of meaning (Thought).

The data obtained were analyzed using Herbert Blumer's symbolic interaction theory as a theoretical framework. Documentation techniques are used to strengthen the analysis results. Documentation techniques help researchers explore data from books, literature, and documents related to this research.

\section{Results and Discussion}

\section{Communication at Darul Ashom Islamic Boarding School for the Deaf, Yogyakarta}

Darul Ashom Islamic Boarding School was established on September 14, 2019. Darul Ashom Islamic Boarding School is located on Jl. Sumatra No. C11 Kayen, Condongcatur, District Depok, Sleman Regency, Yogyakarta Special Region. Abu Kahfi leads this Islamic boarding school. He is a religious expert who previously preached in Bandung. Abu Kahfi as the caretaker of the Islamic boarding school with his family, has long interacted with the deaf using various approaches. Abu Kahfi also participates in various activities of the deaf community so that the sign language skills of Abu Kahf and his family are advancing. The rapid development of the Darul Ashom Islamic Boarding School is very observable from the number of students who continue to increase every year. In 2021, 60 male students and 25 female students were registered. The deaf students who study at the Darul Ashom Islamic Boarding School consist of various ages. In addition to receiving education in religious sciences, deaf students also receive general education by attending homeschooling.

The activities of deaf students at the Darul Ashom Islamic Boarding School are as common as other Islamic boarding schools, but more specifically in memorizing the Quran. Deaf students with dynamic activities also require their supervisors to arrange effective communication strategies. The Darul Ashom Islamic boarding school does not require students to communicate orally or teach students to make sounds like some special schools for the deaf. As stated by ustadzah Bela.

"We have never required or even trained students to produce their voices. God gives them that; usually, they communicate not using voice but using other languages, which is maximized. Because practicing sound means hurting them because the organs do not support it. It requires teachers/ustadzah to be proficient in their language from these limitations. Even we want to master their language that they sometimes forget that we are normal."

The teachers/Ustazah strive for effective communication within the Darul Ashom Islamic Boarding School. Effective communication is an intermediary to achieve the main goal of the Darul Ashom Islamic Boarding School, which is to produce the disabilities who memorize the Qur'an and are religious experts. The majority of the students are still classified as youngsters. Most of 
them initially cannot use sign language, but they eventually get used to it because all the students and ustadzah use sign language. The communication pattern among ustadzah and students becomes more in-depth because they are involved in various Darul Ashom Islamic Boarding School activities. The cycles and patterns of communication in the Darul Ashom Islamic Boarding School are presented in Figure 1.

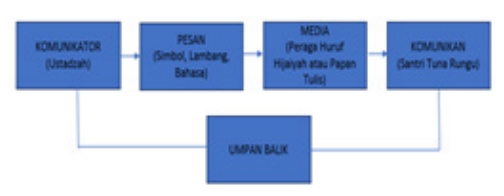

Figure 1 Cycles and Communication Patterns at Darul Ashom Islamic Boarding School Yogyakarta.

As shown in Figure 1, communication leads explicitly to communication during teaching and learning activities, not nonformal daily communication activities. Ustadzah uses learning media in picture props and blackboards to explain hijaiyah letters. Examples such as defining the form of Allah's pronunciation (آلهُ) when connected. It is necessary to describe the shape of the accent because the memorization method used is to demonstrate one by one the letters of a verse or pronunciation.

\section{Symbols in the Interaction of Ustadzah and Deaf Students at Darul Ashom Islamic Boarding School}

The process that presents symbols, meaning interaction, nonverbal communication, and verbal communication is symbolic. Language as a symbol contains various rules that need to be agreed upon to achieve the purpose of communication, explicitly interpreting or delivering a message (Mulyana, 2005). In his theory of symbolic interaction, Blumer stated that language is one of the components involved in symbolic interaction. In this consideration, the language mentioned by Blumer manifests itself in several forms. The language that contains a meaning is also present in the interactions in the Darul Ashom Islamic Boarding School circumstances. The language current in the ustadzah's communication with the students is dominated by non-verbal language.

\section{a. Spoken Language}

Spoken language is a type of language that makes the mouth, throat, and vocal cords the main components. This language type means that sound evolves the main instrument in spoken language. Several things need to be considered in spoken languages, such as articulation in pronunciation, language composition, and word choice. In addition, spoken language should regulate sound rules such as voice volume, sound pressure issued, facial expressions expressed, and body movements or gestures to express the idea of the perpetrator (Syarifudin \& Raditya, 2016).

Deaf students at Darul Ashom Islamic Boarding School are limited in using spoken language, and not all students can use it. The symbol included in spoken language in the environment of deaf students that are most often encountered is laughter. Thus, deaf students will only hear their voices when they laugh. Laughter is a symbol that implies a happy or cheerful mood. Laughter symbolizes pleasure and happiness for the atmosphere around them.

\section{b. Body Language}

This body language relies on physical actions, for example, by showing body movements or facial expressions. This body language can be an instrument of communication under certain conditions 
(Syarifudin \& Raditya, 2016). Some deaf students who are still seven years old or juvenile students who have just joined the boarding school rely on communication using body language, as explained by Ustadzah Umi Kahfi.

"For these young students, they usually don't understand sign language. So they often use body language, but because he can't sign yet, he tends to be quiet while observing his friends who are chatting in sign language." (Interview with Informant Ustadzah Umi Kahfi on May 25, 2021)

This body language is also known as sign language. The type of language that does not involve sound but uses hand, body, and lip movements to deliver a message is called sign language. Thus, sign language does not include sound but contains a combination of body movements such as feet, hands, arms, and the face. Sign language is also one of the language types often used in communication for the deaf (Huda, 2019).

The majority of deaf students at Darul Ashom Islamic Boarding School use sign language to communicate. Teaching and learning activities also use sign language, for example, memorizing the Qur'an, Fiqh Studies memorizing hadith, and studying hadith. The supervisor or ustadzah also masters sign language to conduct the teaching and learning process fluently.

\section{c. Image Symbol}

Communication among ustadzah and students continually uses image media. Pictures are used when introducing foreign objects to juvenile students aged seven to eight years old (Syarifudin \& Raditya, 2016). The use of pictures is relatively effective because students can understand and grasp the meaning of the message given by the teacher. The use of this image symbol is carried out when studying general science with the homeschooling teaching team.

Ustadzah uses pictures to explain the content of the hadith or material about the story of the prophet. Simple illustrations describe the content of hadith, for example, a hadith that contains suggestions for increasing gratitude. Ustadzah illustrates by drawing humans with many blessings such as having money, houses, food, and the like. The illustrations are explained in sign language.

\section{Effective Communication through Symbolic Interaction among Teachers and Deaf Students at Darul Ashom Islamic Boarding School Yogyakarta.}

The primary orientation of the meaning process is the crucial point of symbolic interaction. Herbert Blumer stated this orientation into three things. First, the basis of meaning and the meaning possessed by a person is always in line with action. Second, a person's interaction process then constructs meaning. Third, flexible and interpretative responses in the subsequent interaction process can modify the meaning. This critical process is divided into three elements: meaning, language, and thought, leading to a symbol's interpretation.

Deaf students have many activities in the learning process. The Darul Ashom Islamic Boarding School focuses on creating a generation with disabilities who memorize the Qur'an with high Islamic religious knowledge so that the activities of deaf students are dominated by learning about religious sciences according to the established curriculum.

The teacher or ustadzah and the deaf students also create new symbols. Interaction 
is dominated by sign language, but several symbols are used in addition to signing language. The symbolic interactions among students and ustadzah emerge in several activities, including tahsin, depositing the memorization of the Qur'an and hadith, studies of fiqh and hadith, and murojaah and simaan.

\section{a. Tahsin}

Tahsin comes from hasana, yahsunu, or husna, which means excellent or good. The literal meaning of the word Tahsin is "to be good" (Development Team, 2003). Tahsin AlQur'an means shaping the practice of reading the Qur'an to be better and following the legal rules of tajwid. In addition, tahsin also beautifies the reading of the Quran (Setiawan, 2015).

The tahsin Al-Qur'an activity is a process of teaching about the letters in the Qur'an by ustadzah to deaf students at Pondok Darul Ashom. This tahsin activity will lead deaf students to memorize and understand hijaiyah letters. These hijaiyah letters are taught by the ustadzah using the one-handed method. The interactions or conversations during the tahsin process are also dominated by sign language. In addition to using sign language, tahsin activities assist with props and pictures of hijaiyah letters, as shown in Figure 2.

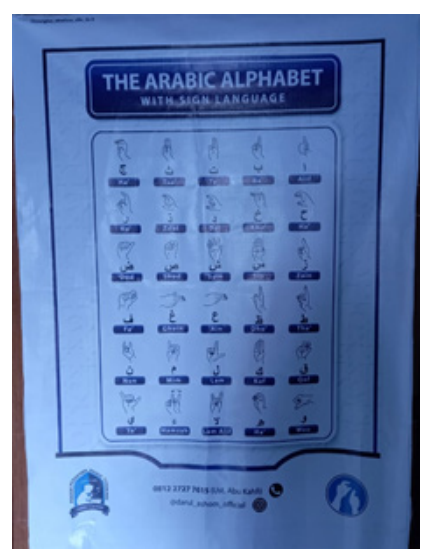

Figure 2. Hijaiyah Letters Props
The tahsin activity is the beginning of a necessary learning process that guides deaf students to memorize the Qur'an and hadith. Tahsin was maintained intensively with the "one ustadzah one student" method. The time required for the tahsin process varies for each student, depending on each student's capability. Generally, the tahsin process takes one week. The process of symbolic interaction can be observed in sign language symbols and pictures.

The process of symbolic interaction is noticed in this activity, in line with Blumer's theory that symbolic interactionism involves three aspects: thought, language, and meaning. Language as a symbol in tahsin activity is sign language and pictures. Sign language and pictures are symbols used by ustadzah to communicate messages to deaf students. The students then apprehend these symbols until they transmit the thought process to their understanding or meaning of the symbols given.

Most of the deaf students previously did not recognize hijaiyah letters, so the ustadzah explained the essence of hijaiyah letters according to the students' developmental age.

The message sent by the ustadzah in the tahsin activity can be communicated well, as evidenced by the majority of students being able to catch, understand, and memorize the signs of the hijaiyah letters. However, the memorization and capture processes require various times for each student. Symbolic interactionism leads the learning process, including tahsin activities, to conduct sufficiently because this symbolic interaction delivers effective communication in the tahsin process among ustadzah and deaf students. 


\section{b. Al-Qur'an and Hadith Memorizing Deposit}

Al-Qur'an memorization deposit activities are carried out at Maghrib and Fajr, while hadith are carried out after Asr. The amount of memorization deposit is different for each student. Some students can memorize up to eight verses. Nevertheless, some can only memorize one or two verses. Students make a memorization deposit using sign language and are directly tested by the ustadzah. Deaf students deposit their memorization using sign language following the tahsin taught before.

Deaf students memorize verses of the Qur'an and hadith by memorizing the arrangement of letters from a verse, as in the illustration in Figure 3.

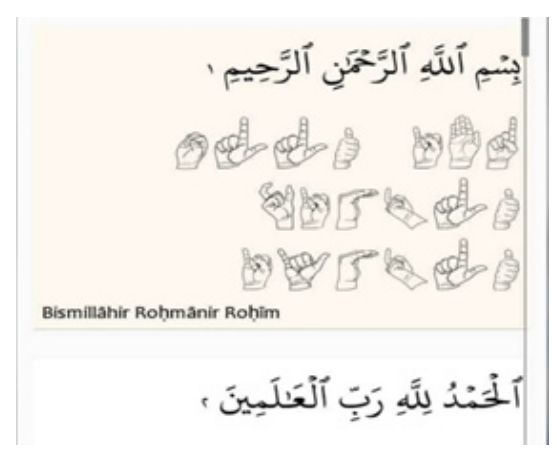

Figure 3 Bismillah Reading Using Hand Sign Symbols.

Figure 3 shows that deaf students in memorizing the Quran have a diverse method from ordinary people. Blumer's theory that symbolic interactionism involves three aspects: thought, language, and meaning. In this research, language appears in symbols in tahsin activities, specifically sign language and pictures as demonstrations tools. Sign language and pictures are symbols used by deaf students to learn to read and memorize the Qur'an. In general, ordinary people memorize the Qur'an word by word, while the deaf is from a letter by letter.

"I never demanded memorization of students because the method of memorizing for the deaf is also more complicated than ordinary people. For example, if ordinary people memorize bismillah with nine syllables (bis mi lah hi roh man nir ra him) while the deaf to memorize bismillah must memorize 19 letters ( $b a^{\prime}$ sin mim alif...) and so on" (Interview with Umi Kahfi, May 25, 2021).

Deaf students are not targeted for extensive memorization because the ustadzah realizes that the memorization method for the deaf is more complicated than memorizing the Quran for ordinary people.

The practice of symbolic interaction arises in deposit activities and is caught when students demonstrate the verses memorized verses and the ustadzah listens to the students' hand movements which contain the meaning of a series of verses.

The meaning implied by Blumer can analyze from the ustadzah, who nods and accepts and continues to listen as evidence that the student's verse is appropriate or correct. Ustadzah will provide corrections if there are errors in demonstrating the hijaiyah letters. Valuing the verse conveyed by the students requires knowledge of the correct sound or lafadz of the verse. Blumer calls this knowledge with thought. The knowledge capacity possessed by the ustadzah/teacher, in this case, is memorizing $30 \mathrm{Juz}$ in the Qur'an. This knowledge helps the ustadzah in capturing the meaning or correct lafadz of a verse that is demonstrated by deaf students when depositing the memorization of the Qur'an. This method makes deaf students feel comfortable during interaction and communication. Effective communication is manifested in the Darul Ashom Islamic Boarding School for the deaf, as expressed by 
Tiyas, a deaf student:

"I like to memorize the Qur'an with the ustadzah here. Because they can speak sign language, they are not arrogant, and people can even think that the ustadzah is a deaf person too" (Interview with Tiyas, deaf student, October 1, 2021)

The capacity or ability of the ustadzah in mastering sign language also contributes significantly to the level of students' knowledge. The deaf students feel very helpful and comfortable in interacting and communicating.

\section{c. The Study of Fiqh and Hadith}

The fiqh study contains the fiqh of worship, such as the procedure for prayer and ablution, while the study of hadith discusses the meaning or intention composed in a hadith. Sample of hadith study material is shown in the following hadith.

From Abu Hurairah radhiyallahu 'anhu, he said that the Prophet Muhammad sallallaahu 'alaihi wa sallam said:

"Do you know that if there was a river near the door of one of you, and he bathed in the water five times a day, would he leave even a little dirt left?" The companions replied, "There will not be a trace of dirt left." He said, "So that is the example of the five daily prayers, by which Allah takes away sins." (Narrated by Bukhari no. 528 and Muslim no. 667)

In delivering the analysis of hadith, Ustadzah represented it literally and explained the contextual meaning of the hadith.

In fiqh studies, teachers often explain sign language and body language, demonstrating the taught. For example, the material about takbiratul ikhram, the ustadzah, shows the takbiratul ikhram movement and explains some things about takbiratul ikhram with sign language assisted by oral language.
According to Blumer, symbolic interaction in hadith study activity is also expressed from the symbols that operate as languages. Sign language, mouth (oral) movements and body movements become symbols teachers use to transfer meaning. The students will listen carefully and digest the substances behind the symbols. In the communication process among students and ustadzah, sometimes misunderstandings arise. For example, the explanation of the hadith regarding the recommendation to take a bath before prayer initially meant that bathing had to be done five times a day.

The process of meaning to students follows what is stated by Blumer's theory. Blumer said that the process of meaning in symbolic interaction also involves thought or mind. The mind influences the meaning among the students and a symbol given by the teacher when studying hadith. The students' meaning towards the study of hadith is often also influenced by previous innate knowledge. As the student's interpretation of the hadith is that bathing before prayer is a recommendation, it is practiced by bathing five times a day because, for Muslims, the obligation to pray is five times a day.

The symbolic interaction in fiqh and hadith learning activities is evidenced by the presence of the components in the symbolic interaction. Language, meaning, and thought construct a form of symbolic exchange, which can lead to effective communication in fiqh and hadith study between ustadzah and deaf students.

\section{d. Murojaah and Simaan}

Symbolic interactions are shown in simaan and murojaah activities. Murojaah is an activity of repeating or re-reading the Quran memorization independently. 
Meanwhile, simaan is an activity identical to an exam that requires students to recite by rote. If a student has memorized one Juz, there will be a simaan schedule given to the student. This simaan activity is similar to a memorization test.

"Simaan is accomplished once a month. The students often get tired of their hands because murojaah and simaan activity takes a long time. The students sometimes show a grinning face and hold his hand while demonstrating the reciting of the Qur'anic verse is a sign of tired or achy, hehe" (Interview with Umi Kahfi, May 25, 2021)

The memorization test is carried out once a month, and each student accomplishes according to the acquisition of memorization for one month. The murojaah activity was carried out by two students taking turns listening to the memorization being demonstrated. Meanwhile, a deaf student will accomplish simaan, and ustadzah will listen carefully; both activities use sign language.

Students will demonstrate the reading of the verses of the Qur'an by reading signs, and ustadzah will listen so that they can catch the meaning of the verse that is being communicated. The practice of symbolic interaction in simaan activities has similarities to deposit activities. Santri uses sign language by demonstrating hijaiyah letters by hand. Furthermore, the ustadzah listens and catches the message, or Blumer's terminology is the meaning, from the hand movements of the students. The meaning acquired by the ustadzah is confirmed and validated with the ustadzah knowledge, which has memorized the Qur'an. The ustadzah often asks the students to repeat the demonstration because they made a mistake in demonstrating. The deaf students also feel that murojaah activity is challenging and requires detailed preparation, as stated by the deaf student Nanda.

"Murojaah is difficult. It took a long time to prepare. We often make mistakes because many verses are similar." (Interview with Nanda, October 1, 2021)

Errors in displaying verses often appear because of the many similar verses. Realizing students' mistakes during memorizing, murojaah, and simaan is a thought process in symbolic interaction. Effective communication is achieved in murojaah and simaan activities, as evidenced by transferring meanings in symbolic interactions.

\section{Conclusion}

Darul Ashom Islamic Boarding School for the Deaf, Yogyakarta, a specific boarding school for disabled students, has an effective communication pattern. The effective communication pattern is constructed on the symbols in the communication process. Effective communication furthermore supports the success of teaching and learning activities and memorizing the Qur'an in the boarding school circumstances.

This effective communication appears in Tahsin, Murojaah, and simaan activities, studies of hadith and fiqh, and the process of memorizing hadith and the Qur'an.

Components influence communication effectiveness in symbolic interactions such as language, meaning, and thought. Language includes sign language, spoken language, and image symbols. Meaning is the message behind the symbol or language, and this meaning also emerges perfectly supported by the ustadzah's ability to use language and symbols in communication. Thought is the part that influences the process of meaning. Knowledge 
of communicant ideas helps to catch the real meaning of communication. In this context, knowledge significantly influences the ustadzah listening or receiving a student's memorization deposit. Without sufficient knowledge, the ustadzah will not catch the verse being presented by the students. This communication pattern has many impacts, one of which is the achievement of the goal of the Darul Ashom Islamic Boarding School in creating a disabled student who has religious experts and memorizes the Qur'an.

\section{References}

Abdullah, N. (2013). Mengenal Anak Berkebutuhan Khusus. Magistra, 86, 10.

Ahmadi, D. (2008). Interaksi Simbolik: Suatu Pengantar. Mediator: Jurnal Komunikasi, 9(2), 301-316. https://doi. org/10.29313/mediator.v9i2.1115

Andriansyah, A. (2018). Komunikasi Interpersonal Terapis dan Wali Terapi dalam Perkembangan Bahasa Murid Tunarungu di UPTD Anak Berkebutuhan Khusus Kabupaten Sidoarjo.

Azwar Saifuddin. (2011). Metode Penelitian. Pustaka Pelajar.

Bela. (2021, Mei 30). Wawancara tentang Pola Interaksi antara Ustazah dengan Santri Tuna Rungu [Komunikasi pribadi].

Efendi, M. (2006). Pengantar Psikopedagogik Anak Berkelainan Khusus. Bumi Aksara.

Huda, N. (2019). Aplikasi Bahasa Isyarat Pengenalan Huruf Hijaiyah Bagi Penyandang Disabilitas Tuna Runggu. $08,6$.

Hutapea, E. (2016). Identifikasi Diri Melalui Simbol-Simbol Komunikasi (Studi Interaksionisme Simbolik Komunitas
Pemakai Narkoba Di DKI Jakarta). Jurnal Bricolage, 2(1).

Kholisnawati, K. (2016). Metode dan Media Menghafal Al-Qur'an Bagi Santri DifabelTunanetra di Pondok Pesantren Hidayatul Qur'an Semawung Daleman, Kutoarjo, Purworejo (Doctoral dissertation, Universitas Alma Ata).

Laksmi, L. (2018). Teori Interaksionisme Simbolik dalam Kajian IlmuPerpustakaan dan Informasi. Pustabiblia: Journal of Library and Information Science, 1(2), 121. https://doi.org/10.18326/ pustabiblia.v1i2.121-138

Liga, W., \& Fernando, E. (2017). Perancangan Aplikasi Komunikasi Penyandang Tunarungu Berbasis Android. 12(1), 12.

Maghfira, T. A., \& Mahadian, A. B. (2018). Interaksi Simbolik Pengajar dan Siswa di Komunitas Matahari Kecil. Jurnal Komunikasi Global, 7(1),87-104.https:// doi.org/10.24815/jkg.v7i1.10540

Mailinda, M., \& Azeharie, S. S. (2019). Komunikasi Interaksionisme Simbolik Antara Pekerja Tunarungu Dengan Tamu (Studi Komunikasi di Kafe Kopi Tuli Depok). Koneksi, 2(2), 426. https:// doi.org/10.24912/kn.v2i2.3919

Maisyaroh, N., \& Praceka, P. A. (2016). Memahami Green Journalism dalam Cover Republika (Studi Analisis Semiotika pada Edisi Kamis 8 Oktober 2015) (Doctoral dissertation, Universitas Sultan Ageng Tirtayasa).

Mulyana, D. (2005). Ilmu Komunikasi Suatu Pengantar. Remaja Rosdakarya.

Musoliyah, A. (2019). Pemenuhan Hak-hak Anak Berkebutuhan Khusus dalam Perspektif Undang-Undang Nomor 8 Tahun 2016 tentang Penyandang 
Disabilitas: Studi Kasus Di Desa Sonoageng Kecamatan Prambon Kabupaten Nganjuk. Sakina: Journal of Family Studies, 3(2).

Nanda. (2021, Oktober 1). Wawancara tentang Pola Komunikasi Santri Tuna Rungu [Komunikasi pribadi].

Nida, F. L. K. (2013). Komunikasi Bagi Anak Berkebutuhan Khusus. 1, 27.

Rafif, A. A. (2020). Implementasi Habitual Learning untuk Penyandang Disabilitas Mental di Pondok Pesantren Ainul Yakin Gunung Kidul Yogyakarta. In The Indonesian Conference on Disability Studies and Inclusive Education (Vol. 1, pp. 63-80).

Restendy, S. (2019). Model Belajar Dan Komunikasi Anak Disabilitas Tunarungu Wicara Di Taman Pendidikan Al Quran Luar Biasa (Tpqlb) Spirit Dakwah Indonesia Tulungagung.Jurnal Komunika Islamika: Jurnal Ilmu Komunikasi dan Kajian Islam, 6(1), 58. https://doi. org/10.37064/jki.v6i1.5519

Ritzer, G., \& Goodman, D. J. (2002). Teori Sosiologi (Terjemah). Kreasi Wacana.

Rusli, R. W. (2019). Khaidir Sangngaji Difabel yang Mendirikan Pesantren Babussa'adah Bajo Kabupaten Luwu Sulawesi Selatan (1957-2019). AlQalam, 25(2), 253-270.

Saihu, S. (2019). Komunikasi Pendidik Terhadap Anak Berkebutuhan Khusus di Sekolah Khusus Asy-Syifa Larangan. Andragogi: Jurnal Pendidikan Islam dan Manajemen Pendidikan Islam, 1(3), 418-440. https://doi.org/10.36671/ andragogi.v1i3.66

Setiawan, D. I. (2015). Pelaksanaan Kegiatan Tahsin Al-Qur'an dalam Meningkatkan
Kemampuan Membaca Al-Qur'an Mahasiswa di Ma'had Sunan Ampel AlAly Universitas Islam Negeri Maulana Malik Ibrahim Malang. Universitas Islam Negeri Maulana Malik Ibrahim.

Siregar, N. S. S. (2012). Kajian Tentang Interaksionisme Simbolik. Perspektif, 1(2), 100-110.

Solin, M. (2010). Peranan Bahasa Indonesia Dalam Membangun Karakter Bangsa. Jurnal Bahas, 20(03).

Sugiono. (2017). Memahami Penelitian Kualitatif. Alfabeta.

Huda, A. N. (2018). Pendidikan Inklusif dari Pesantren. Idrak: Journal of Islamic Education, 1(1), 33-48.

Syarifudin, A., \& Raditya, A. (2016). Interaksi Simbolik Antara Shadow dengan Anak Autis di" Sekolah Kreatif" Surabaya. Jurnal Analisa Sosiologi, 5.

Tamunu, V. R., Waan, F. J., \& Tumengkol, S. M. (2018). Analisis Interaksionisme Simbolik Terhadap Penyimpangan Perilaku Siswa (Kajian Sosiologi Pendidikan Terhadap Pelanggaran Tata Tertib Siswa Di SMA Negeri 9 Manado). HOLISTIK, 21.

Tim Penyusun. (t.t.). Kamus An Nur. Halim Jaya.

Tiyas. (2021, Oktober 1). Pola Komunikasi Santri Tuna Rungu [Komunikasi pribadi].

Umi Kahfi. (2021, Mei 25). Wawancara tentang Pola Interaksi Ustazah dengan Santri Tuna Rungu [Komunikasi pribadi].

Yani Hendrayani, Shilvy Narulita Eka Sari, \& Anjang Priliantini. (2019). Pola Komunikasi Guru Kepada Siswa Penyandang Disabiltas. Jurnal Penelitian Komunikasi, 22(2), 181-194. 